\title{
Crowdfunding. A new option for funding health projects
}

Paula Otero, M.D. ${ }^{a}$

http:/ /dx.doi.org/10.5546/aap.2015.eng.154

\section{INTRODUCTION \\ Definition}

The funding of projects by raising many small amounts of money from a large number of people via the Internet through virtual platforms is known as crowdfunding. It is also known as crowd financing, equity crowdfunding or crowd-sourced fundraising.

At present, it is becoming consolidated as a source to get funds to finance ventures without access to traditional sources of funding, such as loans, grants and fellowships, either because their nature or characteristics do not meet support requirements established by public agencies or because private investors do not find them attractive.

The purpose of crowdfunding is to allow anyone who wants to launch a project to raise the necessary funds from a large number of people who make small donations. ${ }^{1}$

This approach, which started in the United States and has already advanced through Europe, is now slowly being introduced in Latin America. In 2013, more than 1200000 projects were funded worldwide through crowdfunding, without receiving state nor government financial assistance of any kind.

Crowdfunding is also related to social networks, where users play an active role in online communities to share information, knowledge and recommendations about a new initiative and/or brand.

The active participation of users turns them into the key to success for diverse projects since it is them who decide which initiative will receive their support and money. ${ }^{2}$

\section{Types of crowdfunding}

There are different crowdfunding methods based on the type of exchange between funders and beneficiaries and the level of support, so not all crowdfunding projects can be considered a true mode of sponsorship..$^{2-4}$

- Donation-based crowdfunding: this is generally used for charity projects in which there is no monetary exchange for the money received. The only incentive for these projects is social return; collaborators only do it for the satisfaction of seeing projects conducted, so theirs is an intrinsic motivation. It is widely used by non-profit organizations.

- Reward-based crowdfunding: this is used for projects whereby funders receive a reward as retribution, which may range from a mention in social networks to an object representing their donation. This type of funding may be used by any venture or project and has now become a widely implemented method.

- Equity-based crowdfunding: in this case, funders receive shares or equity in any profit made by the project or a recognition in the form of a product or service. Investors may receive an end product or service or a discount over the sales price for the general public. This type of funding is used for the development of new technologies, such as diagnostic tests for uncommon pathologies.

- Lending-based crowdfunding: in this case, the parties agree that funding will be in the form of a loan with a specific interest rate. Donors are considered investors who expect a financial 
return, so it becomes an attractive alternative to traditional credits. However, its implementation might be difficult in the field of health research.

The reward system is now becoming the most widely used method, usually by creative companies or businesses that offer small consumer products, where the initial prefinancing stage is linked to a clear initial demand, i.e., if enough people support the project, it will be validated and initial funds necessary for its activities will be collected. ${ }^{5}$

\section{Crowdfunding methodology}

Crowdfunding methodology includes posting a project and promoting it in order to collect the amount of money proposed for the initiative.

Three major parties play a role in planning any crowdfunding campaign: an individual who needs and seeks funding for his/her idea or project, a funder, and a platform that allows them to easily interact and communicate.

Crowdfunding platforms require to establish a deadline for fund collection, the amount of money needed and, if applicable, a reward system based on the amount provided or a commitment to return the money in case the total proposed amount is not reached. These platforms provide tools to make donation transactions, credit card payments or other payment forms, such as bank transfers or via PayPal.

Once posted, the project should be promoted by all means possible (social networks, blogs, web sites, e-mail, etc.). For this reason, social networks may help to inject energy to a proposal which otherwise would have been restricted to family and friends.

\section{Healthcare at present}

Over the past years, we have witnessed a transforming change in medical practice in relation to how science, technology, personalization, mobility and social media are used.

This situation widens the gap between high- and low-resource countries in terms of how aspects related to health and disease are developed, provided and managed by public health.

In addition, traditional medicine displays a reactive approach, whereby diseases are treated once they emerge. For this reason, in order for healthcare to focus on prevention rather than only on treating the sick, it is necessary to transform the reactive model into a proactive one that requires finding a balance between technology and people's participation. Also, the transformation towards a personalized medicine which is both preventive and participative may also call for an increased expense on part of an already financially inefficient health system.

Crowdfunding is now being used for the development of social projects. Healthcare should be considered as a subject of social impact, for example, aid programs targeted at developing countries, the reduction of poverty, and the promotion of new technologies. ${ }^{6}$

\section{What is the niche for health project crowdfunding?}

Although in recent years crowdfunding has proven itself useful to finance, among others, artistic and technological ventures, it has not been profoundly embraced by the healthcare community, whether in the field of research or care delivery. One of the reasons might be that crowdfunding requires a strong online presence and a creator who is both productive and a social media connoisseur, situation which is uncommon in the academic setting, either due to lack of time or lack of incentives for its development. ${ }^{7}$

In general, medical practice and research focus on the pathologies that affect a large part of the population of developed countries. However, some diseases may be considered "orphan" as they do not fall within the main objectives of healthcare. For example, there is no vaccine or proven treatment for certain contagious diseases which are endemic in low-resource countries, such as dengue fever, malaria, Chagas disease and now Ebola. In addition, there are more than 7000 genetic diseases that affect more than 350 million people worldwide; however, their gene sequence is not studied in depth due to their low incidence. These two examples of topics disregarded by traditional medicine have been the focus of crowdfunding projects.

Some USA-based sites are exclusively devoted to these topics and are focused on how to help patients directly, such as Give Forward, Go Fund $\mathrm{Me}$, and You Caring. ${ }^{8}$

In Argentina, crowdfunding is yet to take off. One of the main initiatives with online presence today is Idea.me (http:/ /idea.me/), which was initiated in August 2011 and has managed to fund almost 200 projects, accounting for $30 \%$ of all projects submitted in Argentina, Mexico, Brazil, Chile, and Uruguay. 
The site offers two funding methods. One is All or Nothing, which requires that $100 \%$ of the financial objective is reached before the end of the raising period. If such goal is not achieved, each backer receives its money back. The other method is Everything Helps, which means that even if the goal is not reached, the project can be started and backers receive their rewards. Each project should include an alternative plan for using the raised money, which should be communicated to both Idea.me and all project backers.

On another level, Nobleza Obliga (http:/ / www.noblezaobliga.com) is focused on charity fund raising, and its main objective is to facilitate fund raising for anyone who wants to turn their cause into a reality and generate a positive impact at a community level.

\section{Crowdfunding as a source of funds for health research and innovation}

The financial crisis worldwide has hindered access to credit and funding for basic and clinical research. For this reason, researchers from different countries have adopted crowdfunding to fund their research projects.

Three main factors have been described to help crowdfunding become a viable option to obtain research funds: ${ }^{9}$

- An increasing need for research and development funding.

- The possibility of boosting research protocols and systems.

- Seeking and taking advantage of the potential of this new funding channel for science support.

Although these mass funding campaigns may not replace research grants or fellowships based on the small amount of money that can be raised, they may serve as a starting point or to develop pilot studies. Given that these projects could be massively publicized, many times they might work to get the attention of potential investors who may provide a greater financial support. ${ }^{9,10}$

Many different ventures worldwide have used crowdfunding as a kick starter for their funding.

Cameron, et al. ${ }^{11}$ describe their experience with three successful cases of crowdfunding for health research. Genome Liberty used the Rockethub platform to create a company that provides genome sequencing and interpretation directly to patients at a lower cost by working against a patent legislation that created a gene analysis monopoly. The project was successful for the breast cancer BRCA1 gene, whose patent was exclusively owned by Myriad Genetics. Each patient had to pay USD 3000 for each test, while other labs had the technology to do it for USD 200. The fund raising campaign reached USD 10000 and helped to develop genetic markers available to patients at an affordable price. In turn, the campaign promoted the development of other similarly successful initiatives, such as Rare Genomics, which helps children with rare genetic diseases to have their genes sequenced. ${ }^{12}$

Another campaign was PathoMap, posted through the Indiegogo platform. Its objective was to analyze microorganisms found on common public surfaces, such as subway handrails or a New York park bench, in order to prevent the spread of contagious diseases by sending mobile alerts. Although their objective was to raise USD 10000 , the campaign only reached $3 \%$ of its goal. In spite of the low support rate, it helped to get the attention of other companies who got interested in the project, and the final amount raised increased to USD 12 000. These examples describe how innovative and common disease research could create an interest in potential donors.

\section{CONCLUSION}

Crowdfunding is becoming a new source of microfunding for personal and institutional ventures that have not access to traditional financing worldwide. Healthcare and health research are not alien to this trend.

One of the main characteristics of crowdfunding is that it uses collective funding to help any person or institution to carry out their project, whether related to business, culture, society or health, when it is not possible to conduct it through traditional means. An additional value of crowdfunding is that it promotes collaboration among people who have common interests and allows them to broadly disseminate a project that would otherwise go unnoticed.

\section{REFERENCES}

1. Gerber EM, Hui JS, Kuo P-Y. Crowdfunding: why people are motivated to post and fund projects on crowdfunding platforms. Proceedings of the International Workshop on Design, Influence, and Social Technologies: Techniques, Impacts and Ethics; 2012; Seattle, Washington.

2. Ordanini A, Miceli L, Pizzetti M, Parasuraman A. Crowdfunding: transforming customers into investors through innovative service platforms. Journal of Service Management 2011;22(4):443-70.

3. Informe de la encuesta de la Asociación Española de Crowdfunding sobre las plataformas españolas de 
crowdfunding. Asociación Española de Crowdfunding; 2014. [Accessed on: October 14, 2014]. Available at: http: / / web.spaincrowdfunding.org/wp-content/ uploads / 2014/06/INFORME-DE-LA-ENCUESTADE-LA-ASOCIACI\%C3\%93N-ESPA \%C3\%91OLA-DECROWDFUNDING.pdf

4. Mollick E. The dynamics of crowdfunding: An exploratory study. J Bus Venturing 2014;29(1):1-16.

5. De Buysere K, Gajda O, Kleverlaan R, Marom D, et al. A framework for European crowdfunding. European Crowdfunding Network; 2012. [Accessed on: October 14, 2014].Availableat:http:/ /www.europecrowdfunding.org/ files/2013/06/FRAMEWORK_EU_CROWDFUNDING. pdf.

6. Nimita L, Carol IB. The modern social contract between the patient, the healthcare provider, and digital medicine. J Socialomics 2014;3(1):105.
7. Perlstein EO. Anatomy of the Crowd4Discovery crowdfunding campaign. Springerplus 2013;2:560.

8. Sisler J. Crowdfunding for medical expenses. CMAJ 2012;184(2):E123-4.

9. Crowdfunding para la ciencia y la investigación. Revista Vorticex [Internet]. 2013;(1). [Accessed on: October 14, 2014]. Available at: http://www.vorticex.org/revista/ crowdfunding-id/.

10. Kaplan K. Crowd-funding: cash on demand. Nature 2013;497(7447):147-9.

11. Cameron P, Corne DW, Mason CE, Rosenfeld J. Crowdfunding genomics and bioinformatics. Genome Biol 2013;14(9):134.

12. Barclay E. The sick turn to crowd funding to pay medical bills. NPR; 2012. [Accessed on: August 1, 2014]. Available at: http://www.npr.org/blogs/ health / 2012 / 10/23/163489063/the-sick-turn-tocrowdfunding-to-pay-medical-bills. 